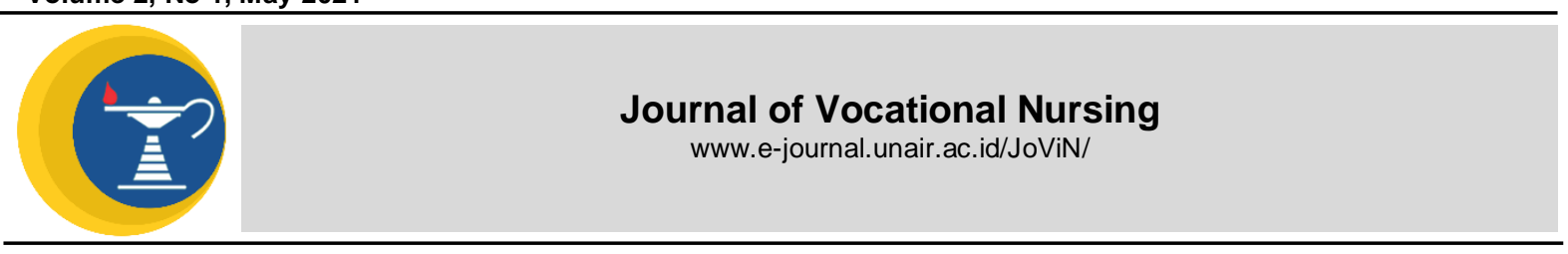

\title{
THE RELATIONSHIP OF KNOWLEDGE, ATTITUDE AND FAMILY SUPPORT WITH THE NUTRITIONAL STATUS OF THE ELDERLY: LITERATURE REVIEW
}

\author{
Maria Ambrosia Barek Tifaona, Joni Haryanto, Elida Ulfiana \\ Faculty of Nursing, Universitas Airlangga
}

Research Report

\section{A B STRACT}

Introduction: Elderly are individuals who are vulnerable and at risk of experiencing health problems related to nutritional status. Families who live together are expected to be able to provide nutritional intake in accordance with the condition of the elderly so that adequate knowledge is needed in preparing the need for balanced nutrition. The purpose of this study was to analyze the relationship between knowledge, attitudes, and family support to elderly's nutritional status. Methods: The search for literature review articles was carried out in four databases (Scopus, Science Direct, Pub med, and Google Scholar) with a publication span of 2016-2020. The prism checklist was used to guide this review. Analysis and data tabulation were carried out in the article. Title, abstract, full text and methodology were assessed to determine study eligibility. Results: $A$ total of 10 studies matched the inclusion criteria of the study, consisting of 6 cross-sectional studies and 4 qualitative studies. A review study found that good knowledge, positive attitude and good family support are directly proportional to the nutritional status of the elderly. Discussion: Family has a role in maintaining the health of the elderly, one of which is in fulfilling nutrition. Knowledge, attitudes and family support are related to the nutritional status of the elderly. Conclusions: Families who have knowledge related to nutrition can provide complete food intake and according to the needs of the elderly. A good family attitude will increase their support in helping fulfill nutrition.
ARTICLE INFO

Received May 20, 2021

Accepted May 30, 2021

Online May 31, 2021

*Correspondence:

Maria Ambrosia Barek Tifaona

*Email:

Maria.ambrosia.barek2019@fkp.unair.ac.id

\section{Keywords:}

knowledge, attitude, family support, nutritional status, elderly

\section{INTRODUCTION}

Elderly is a serious problem because it can be influenced by Add Related Change and Additional Risk Factors (Segerstrom \& Hodgson, 2019). The elderly experience a decrease in the functional capacity of the organs which affects nutritional intake. Attitudes and family support in providing nutritional intake are an important component because the elderly who live with other families usually experience dependence on their daily needs. Families who live together are expected to be able to provide nutritional intake in accordance with the conditions of the elderly so that adequate knowledge is needed in preparing the need for balanced nutrition (Moral-fernándezet al., 2018). If this is not fulfilled, the elderly will experience problems such as hypertension, joint disease, diabetes mellitus, heart disease, dementia and stroke (Moral-fernándezet al., 2018). Research by Zhao, Hu, \& Men, (2019) states that the ability of families to meet their needs is highly dependent on family characteristics, economic abilities and basic knowledge of family health status. However, the relationship between knowledge, attitudes and family support with the nutritional status of the elderly still needs to be studied.

According to the World Health Organization, (2017) globally, the nutritional status of the elderly reached $37 \%$ good, $35 \%$ sufficient and $28 \%$ less. $26 \%$ of the elderly who live with their family are accompanied by disease, $26 \%$ of them have less and more nutritional status and only $2 \%$ have good nutritional status the nutritional status of the elderly is estimated to be good about $40 \%$ of the total number and poor by $60 \%$. This is due to physical disturbances. About $20 \%$ of the world's population aged 70 years, and $50 \%$ of the population aged 85 years reported experiencing difficulties in meeting nutritional needs due to a lack of family understanding of elderly nutrition, tooth decay, economic status, 
living alone, and unavailability of food sources (Boltz et al., 2018). As many as $12.8 \%$ of the population aged 65 years and over in Nepal experience a malnutrition status and the most common experienced by people aged 65 years and over is due to living alone and experiencing tooth decay. WHO, (2018) states that the population structure based on age in Asia consists of $15 \%$ of the elderly based on the WHO category with a ratio of nutritional status disorders reaching $32 \%-41 \%$.

Globally the elderly in Asia reach $15.3 \%$ of the current population and $7.3 \%$ of them have problems with nutritional needs. Malnutrition status was the highest with an incidence of $41.87 \%$, then $32 \%$ experienced good nutritional status and the rest was under nutritional status (Lozano, Manyes, Peiró, \& Montes, 2019). The prevalence of malnutrition in the elderly has reached a significant level, namely $17-65 \%$. Research on the elderly who live with their family states that around $25.9 \%$ are in a nutritional deficiency status. The elderly who themselves also showed that half of the sample experienced problems in nutritional status, namely the elderly who experienced an over nutritional status of $14.64 \%$; normal nutritional status $43.9 \%$; and malnutrition status $41.46 \%$ (Balitbangkes Ministry of Health, 2018). In NTT, the majority of elderly people were found at the age of $60-74$ years $(89.3 \%)$ and based on gender were women (54.8\%). Nutritional status based on BMI was found to be the most with normal nutrition (64.5\%) and based on Mini Nutritional Assessment (MNA), the highest yield was with the risk of malnutrition (59.2\%). The basic health survey found that the most results were at the age of 64-70 years and there were more women than men. In terms of nutritional status, the highest yields were found and those at risk of malnutrition (Balitbangkes Kemenkes, 2018).

The main factor that causes poor status is the presence of chronic diseases that often lead to reluctance in the elderly to eat. These chronic diseases include heart disease, hypertension, diabetes, chronic obstructive pulmonary disease (COPD), osteoarthritis, hip fracture, cognitive impairment, dementia, depression., cancer and visual impairments (Chaves, Amaral, Nelas, Carvalho, \& Dionisio, 2012). Research by Aguiar \& Macário, (2017) reports that the important role of the family is needed in meeting the nutritional needs of the elderly. Especially it is important for family awareness to care for and facilitate in the context of examination and management of the elderly's diet.

Efforts to care for the elderly require an important family role. Family has 5 basic functions, namely affective function, socialization function, reproductive function, economic function and health care or maintenance function. In connection with the last function, the family has the obligation to carry out health care practices, namely preventing health problems and / or caring for sick family members. Families participating in child care require the ability to recognize diseases, which are important aspects of care (Or \& Penneau, 2018). Involvement and solid teamwork consisting of doctors, nurses, other health workers, families and sufferers themselves. Families can learn to identify and respond to the pain experienced by the elderly (Badriah \& Sahar, 2018). Develop effective relationships with health professionals. Family centered care emphasizes the importance of involvement and empowerment in providing family care for the elderly. Research shows that family-centered care in practice treats families with care, communicates information to families so that they understand their conditions, involves family participation in family decisionmaking and care, and cooperation between families and caregivers (Taylor \& Hoenig, 2006).

Marinho et al, (2020) in their study of family attitudes towards nutritional fulfillment in the elderly is positively associated with a reduction in chronic disease recurrence. Research by Kristianingrum et al, (2018) found the influence of family support on elderly nutrition management on the ability of the elderly in their daily activities. Research conducted by Jeruszka-bielak et al., (2018) found a positive relationship between family support and the nutritional status of the elderly. Good family support will improve the nutritional status of the elderly. The purpose of this literature review is to analyze the relationship between knowledge, attitudes, and family support with the nutritional status of the elderly based on empirical studies in the last five years.

\section{MATERIALS AND METHODS Literature Search Strategy}

Comprehensive summary in the form of literature review the relationship between knowledge, attitudes, and family support with the nutritional status of the elderly. This study uses The Center Review and The Joanna Briggs Institute Guidelines as a guide in assessing the quality of the studies to be summarized. The evaluation of the literature review will use the PRISMA checklist to determine the selection of studies that have been identified and adjusted for the purposes of the review literature. 
The search for journals or articles for the authenticity of this study using journals in English, with international reputation, which are relevant to the topic, used five databases with high and moderate criteria, namely those from Scopus, Science Direct, google scholar and PUBMED. Literature search is limited to articles published in the last 5 years, namely 2015 2020. Design of this study is a mix method study, experimental study, survey study, cross sectional study, correlation analysis, comparative analysis, qualitative study, narrative review, pilot study.

\section{RESULTS}

Screening stage to data extraction, so the analysis can be carried out by combining all data that meets the inclusion requirements using techniques either qualitatively, quantitatively or both. In this study, after going through the screening stage to data extraction, analysis can be carried out by combining all data that meets the inclusion requirements using techniques either qualitatively, quantitatively or both. In this study, researchers will use both data analysis techniques, namely quantitatively to synthesize research results with a quantitative approach, for example, Cohort Study or Case-Control Study, Cross Sectional Study, Prospective Study / cohort, Retrospective Study, Rapid Review, Observational Study and qualitatively to synthesize (summarize) the results of the descriptive qualitative research.

\section{Study Characteristics}

This literature review study uses 10 articles that have passed screening according to predetermined criteria. The literature search results that have been analyzed and defined in the literature review include the moderate criteria, namely those from Scopus, Science Direct, google scholar and PUBMED. Literature search is limited to articles published in the last 5 years, namely 2015 - 2020. Design of this study is a mix method study, experimental study, survey study, cross sectional study, correlation analysis, comparative analysis, qualitative study, narrative review, pilot study. Database used, the year of publication and the research design

Table 3.1 Characteristics of the article.

Category $\quad$ Total $\quad$ Presentase (\%)

\begin{tabular}{ccc}
\hline Database & & \\
\hline Scopus & 2 & 20 \\
\hline Science Direct & 1 & 10 \\
\hline Pub med & 4 & 40 \\
\hline Google Scholar & 3 & 30 \\
\hline Total & $\mathbf{1 0}$ & $\mathbf{1 0 0}$ \\
\hline Publishing & & 10 \\
\hline 2016 & 1 & 10 \\
\hline 2017 & 1 & 20 \\
\hline 2018 & 2 & 40 \\
\hline 2019 & 4 & 20 \\
\hline 2020 & 2 & $\mathbf{1 0 0}$ \\
\hline Total & $\mathbf{1 0}$ & \\
\hline Research design & & 60 \\
\hline Qualitative & 4 & $\mathbf{1 0 0}$ \\
\hline Cross-sectional & 6 & \\
\hline Total & $\mathbf{1 0}$ & $4)$. (0)
\end{tabular}

Based on Table 3.1, most articles were found in the Pub med database $(n=4)$. Most articles published in $2019(n=4)$. The research design that is widely used to discuss the relationship between knowledge, attitudes and family support with the nutritional status of the elderly is cross-sectional as many as 6 studies or $60 \%$. 
Using a checklist of assessment lists based on The Joanna Briggs Institute (JBI) according to the research design of each article. Broadly speaking, the research design included in this literature review used a cross-sectional research design and qualitative research

Table 3.2 Study Assessment Results

\begin{tabular}{|c|c|c|c|c|c|c|c|c|c|c|c|c|}
\hline \multirow[t]{2}{*}{ Researeher } & \multirow[t]{2}{*}{ Design } & \multicolumn{10}{|c|}{ Assessment Indieators } & \multirow{2}{*}{$\begin{array}{l}\text { Critieal } \\
\text { Appraisal } \\
\text { Score }\end{array}$} \\
\hline & & 1 & 2 & 3 & 4 & 5 & 6 & 7 & 8 & 9 & 10 & \\
\hline $\begin{array}{l}\text { (Nazari, Rusli, \& } \\
\text { Tahlil, 2016) }\end{array}$ & Cross sectional & $\sqrt{ }$ & $\sqrt{ }$ & $\sqrt{ }$ & $\sqrt{ }$ & - & - & $\sqrt{ }$ & $\sqrt{ }$ & & & $(6 / 8) 75 \%$ \\
\hline $\begin{array}{l}\text { (Marshall, } \\
\text { Reidlinger, } \\
\text { Young, \& } \\
\text { Isenring, 2016) }\end{array}$ & $\begin{array}{l}\text { Qualitative } \\
\text { phenomenology }\end{array}$ & $\sqrt{ }$ & $\sqrt{ }$ & $\sqrt{ }$ & $\sqrt{ }$ & $\sqrt{ }$ & $\sqrt{ }$ & - & $\sqrt{ }$ & $\sqrt{ }$ & $\sqrt{ }$ & $\begin{array}{l}(9 / 10) \\
90 \%\end{array}$ \\
\hline $\begin{array}{l}\text { (Jeruszka-bielak } \\
\text { et al., 2018) }\end{array}$ & Cross sectional & $\sqrt{ }$ & $\sqrt{ }$ & $\sqrt{ }$ & $\sqrt{ }$ & $\sqrt{ }$ & - & $\sqrt{ }$ & $\sqrt{ }$ & & & $\begin{array}{l}(7 / 8) \\
87,5 \% \\
\end{array}$ \\
\hline $\begin{array}{l}\text { (Kristianingrum et } \\
\text { al., 2018) }\end{array}$ & $\begin{array}{l}\text { descriptive } \\
\text { phenomenology } \\
\text { method }\end{array}$ & $\sqrt{ }$ & $\sqrt{ }$ & $\sqrt{ }$ & $\sqrt{ }$ & $\sqrt{ }$ & $\sqrt{ }$ & - & $\sqrt{ }$ & $\sqrt{ }$ & $\sqrt{ }$ & $\begin{array}{l}(9 / 10) \\
90 \%\end{array}$ \\
\hline $\begin{array}{l}\text { (Fadillah, } \\
\text { Suyatno, \& } \\
\text { Nugraheni, 2019) }\end{array}$ & Cross sectional & $\sqrt{ }$ & $\sqrt{ }$ & - & $\sqrt{ }$ & - & - & $\sqrt{ }$ & $\sqrt{ }$ & & & $\begin{array}{l}5 / 8) \\
62,5 \%\end{array}$ \\
\hline $\begin{array}{l}\text { (Lao, Low, \& } \\
\text { Wong, 2019) }\end{array}$ & $\begin{array}{l}\text { A descriptive } \\
\text { qualitative }\end{array}$ & $\sqrt{ }$ & $\sqrt{ }$ & $\sqrt{ }$ & $\sqrt{ }$ & $\sqrt{ }$ & $\sqrt{ }$ & - & $\sqrt{ }$ & $\sqrt{ }$ & $\sqrt{ }$ & $\begin{array}{l}(9 / 10) \\
90 \%\end{array}$ \\
\hline $\begin{array}{l}\text { (Nurhayati, } \\
\text { Yuniarti, \& Putri, } \\
\text { 2019) }\end{array}$ & Cross sectional & $\sqrt{ }$ & $\sqrt{ }$ & $\sqrt{ }$ & $\sqrt{ }$ & - & $\sqrt{ }$ & $\sqrt{ }$ & $\sqrt{ }$ & & & $(6 / 8) 75 \%$ \\
\hline $\begin{array}{l}\text { (Kucukerdonmez, } \\
\text { Navruz Varli, \& } \\
\text { Koksal, 2017) }\end{array}$ & Cross sectional & $\sqrt{ }$ & $\sqrt{ }$ & $\sqrt{ }$ & $\sqrt{ }$ & $\sqrt{ }$ & - & $\sqrt{ }$ & $\sqrt{ }$ & & & $\begin{array}{l}(7 / 8) \\
87,5 \%\end{array}$ \\
\hline $\begin{array}{l}\text { (Hestevik, Molin, } \\
\text { Debesay, } \\
\text { Bergland, \& Bye, } \\
\text { 2020) }\end{array}$ & $\begin{array}{l}\text { A qualitative } \\
\text { interpretive } \\
\text { descriptive } \\
\text { design }\end{array}$ & $\sqrt{ }$ & $\sqrt{ }$ & $\sqrt{ }$ & $\sqrt{ }$ & $\sqrt{ }$ & $\sqrt{ }$ & - & $\sqrt{ }$ & $\sqrt{ }$ & $\sqrt{ }$ & $\begin{array}{l}(9 / 10) \\
90 \%\end{array}$ \\
\hline $\begin{array}{l}\text { (Kiesswetter et } \\
\text { al., 2020) }\end{array}$ & Cross-sectional & $\sqrt{ }$ & $\sqrt{ }$ & $\sqrt{ }$ & $\sqrt{ }$ & $\sqrt{ }$ & $\sqrt{ }$ & - & $\sqrt{ }$ & & & $\begin{array}{l}(8 / 8) \\
100 \% \\
\end{array}$ \\
\hline
\end{tabular}

The results of the study assessment using the Joanna Briggs Institute critical appraisal checklist showed that all the articles reviewed got a score of $>50 \%$. This means that all articles meet the criteria for a literature review.

The ten articles that meet the criteria are divided into three major themes, namely 1) the relationship between family knowledge and nutritional status of the elderly; 2 ) the relationship between family attitudes and nutritional status of the elderly; 3) the relationship between family support and the nutritional status of the elderly. Most of the articles show that the nutritional status of the elderly is in the good category with a percentage of $65 \%$, and the remaining $20 \%$ is sufficient and bad at $15 \%$. Nine articles used anthropometric measurements to determine the nutritional status of the elderly and 1 article used the Mini Nutritional Assessment-Short Form (MNA-SF).

\section{DISCUSSION \\ Relationship between Family Knowledge and Elderly Nutritional Status}

Based on the results of the literature review, it was found that there was a relationship between knowledge and nutritional status in the elderly. The higher the level of family knowledge, the better the nutritional status of the elderly (Nurhayati et al, 2019). Family knowledge has an impact on the nutritional support they provide to the elderly (Marshall et al., 2016).
Families need knowledge and skills to provide adequate care for the elderly regarding nutritional needs (Kurata and Ojima, 2014). This knowledge is obtained through the perception of stimuli using the senses, the results of the perception in the form of information will be stored in the memory system to be processed and given meaning, then. This information is used (retrieval) when needed. A person can gain knowledge by optimizing his perceptual abilities and attention and managing information storage in an orderly 
manner (Notoatmodjo, 2012). The level of knowledge possessed by respondents is influenced by several factors, including the level of education, sources of information and a person's characteristics. Knowledge or cognitive is a very important domain for the formation of one's actions or over behavior (Notoatmodjo, 2012). In fact, behavior based on knowledge will be more lasting than behavior without knowledge. The knowledge needed by the family regarding numbers. The information needed by the family regarding the nutritional needs of the elderly is nutritional needs in accordance with the condition of the elderly's disease, both mineral, vitamin and other nutritional needs (Marinho et al., 2020). Families with elderly people must have sufficient knowledge about what actions to take to choose the food consumed by the elderly. Knowledge also provides understanding to families, especially in terms of serving food, knowledge that is less likely to provide food that is not suitable for the needs of the elderly (Hooft et al, 2015).

Family knowledge about the provision of nutrition to the elderly indirectly determines the nutritional status of the elderly, this is because the family is responsible for the nutritional status of the elderly. By serving food that is modest without considering the meal according to the nutritional needs of the elderly. Affect the nutritional needs of the elderly (Chaves et al., 2012). Families must to know the factors that affect the nutritional needs of the elderly with reduced ability to digest food due to tooth decay or toothlessness. The reduced sense of taste results in a decrease in sweet, salty, sour, and bitter tastes. The esophagus or esophagus is enlarged. Hunger decreases, stomach acid decreases. Bowel movements or peristaltic movements are weak and usually cause constipation (Lin \& Ms, 2015).

Marshall et al., (2016) stated that the knowledge needed by families in providing proper nutritional intake for the elderly is knowledge about the diseases and daily needs of the elderly, knowledge about foods that can be consumed or not and knowledge related to the history of disease that has been suffered. By the elderly. Meanwhile, Nurhayati et al., (2019) explained that the most important knowledge is the physical condition of the elderly related to the disease suffered by the need for daily nutrition.

Families with a good level of knowledge, especially those related to nutritional fulfillment for the elderly, will have a good impact on the nutritional status of the elderly. Family knowledge will influence the actions and behavior of the family in fulfilling the nutrition of the elderly. Most of the respondents in the study have knowledge in a good category so that it allows the family to have the ability to fulfill the nutrition of the elderly.

\section{Relationship between Family Attitudes and Elderly Nutritional Status}

A literature review found that there was a relationship between family attitudes and nutritional status in the elderly. A good family attitude is the more persistent, voluntary or proactive they are in providing nutritional support for the elderly (Marshall et al., 2016). Family attitudes towards nutrition in the elderly provide nutritional value, confidence, and knowledge so that they become persistent and are used in determining the types of nutritional support strategies that are good for the elderly. The type of belief or attitude related to nutrition, and how strong the value is, in turn influences the nutritional priorities and strategies used by the family (Marshall et al., 2016). The family attitude is an attitude that is directed to other individuals and has an active influence as well as the attitude of the family towards the elderly (Rodgers, 2012).

A literature review found that there was a relationship between family attitudes and nutritional status in the elderly. A good family attitude is the more persistent, voluntary or proactive they are in providing nutritional support for the elderly (Marshall et al., 2016). Family attitudes towards nutrition in the elderly provide nutritional value, confidence, and knowledge so that they become persistent and are used in determining the types of nutritional support strategies that are good for the elderly. The type of belief or attitude related to nutrition, and how strong the value is, in turn influences the nutritional priorities and strategies used by the family (Marshall et al., 2016). The family attitude is an attitude that is directed to other individuals and has an active influence as well as the attitude of the family towards the elderly (Rodgers, 2012).

Notoatmodjo, (2012) states that the process of forming a person's attitude related to his / her health is included in the use of family latrines which are classified into 4 (four) parts, namely: (1) there is an assessment of the person concerned about individual health disorders or threats; (2) anxiety arises because of the disorder, in this case it is realized that any health problem will cause anxiety both for the person concerned and for his family members; (3) application of the knowledge of the person concerned regarding matters relating to health problems, in particular regarding the disorder he or she is experiencing. From here people 
collect various ways to deal with these health problems, both traditionally and in a modern way, the various ways of applying knowledge both in gathering various kinds of disorders and ways to overcome them are a reflection of various forms of behavior; (4) manipulative actions are taken to eliminate or eliminate the anxiety or disorder, In this case, people will make an effort to overcome family health problems that have a positive attitude towards fulfilling elderly nutrition, so the family tends to be sensitive to the needs of the elderly so they try to help meet these needs. This has an impact on the nutritional status of the elderly, meaning that families who volunteer without any encouragement will be able to provide good nutritional support for the elderly.

\section{Relationship between Family Support and Elderly Nutritional Status}

Based on the results of the literature review, it was found that 9 out of 10 articles explained the relationship between family support and the nutritional status of the elderly. The active role of the family affects the suitability of the practice of balanced nutrition in the elderly. The better the active role of the family, the better the suitability of nutritional practices in the elderly and it can be predicted that it will increase 0.29 times better (Fadillah et al., 2019). Family plays a role in providing support in providing nutritional care for the elderly. The family provides support in the form of financial support and the needs of the elderly so that a lot of family support is directed at supporting the improvement of the nutritional status of the elderly (Hestevik et al., 2020).

Family plays a role as a source of information for the elderly regarding nutrition (Jeruszka-bielak et al., 2018). Limited mobility as a risk factor for malnutrition in the elderly. This can be a sign of adequate support from family members and caregivers regarding shopping and meal preparation (Kiesswetter et al., 2020). Family support felt by the elderly includes assistance with daily activities, assistance to obtain health services, food preparation, financial assistance, attention, guidance, and problem solving (Kristianingrum et al., 2018). Family support includes involvement in the nutrition of the elderly. Good family support will also result in a good nutritional status for the elderly (Lao et al., 2019). The family is obliged to provide nutritional support. Family knowledge has an impact on the nutritional support they provide. The better family ethos / attitude affects the persistence, ambition or proactiveness of the family in providing nutritional support for the elderly (Marshall et al., 2016). There is a relationship between family support and nutritional fulfillment in the elderly (Nazari et al., 2016). Family support is related to the nutritional status of the elderly. The results of this literature review are in line with the research of Vriastuti and Suratini (2014) which reports that there is a relationship between family support and nutrition in elderly people who have a history of hypertension. Péter et al., (2015) stated that the factor that contributes to the decline in nutritional status in the elderly is the burden of life supported by comorbidities in the elderly such as cardiovascular disease and metabolic disease with a possible contribution. Elderly families affect the quality of life of the elderly, starting from caring for, maintaining health and welfare of the elderly. One of the ways to care for the elderly is to provide and provide food for the elderly. The food content provided not only provides a feeling of fullness but also takes into account its nutritional content. The nutritional content of food consumed by the elderly will affect their health.

The burden of life here means that the elderly are fully responsible for themselves without being supported by a partner or family. So it can be concluded that the elderly who do not have family support are at greater risk of having an impact on nutritional status compared to the elderly who live with the family (Nazari et al., 2016). Elderly who live alone or are left behind by loved ones without the support of friends or family have an impact on changing their nutritional status, therefore to meet their needs requires support from family (Nurhayati et al., 2019).

Family members are the main source of support for the elderly (Schulz, Beach, Czaja, Martire, \& Monin, 2020). Nutritional care both in the hospital and at home appears to lack a person-centered approach that recognizes and values the whole person, taking into account the needs and desires of the elderly taking into account the biological, social and psychological aspects that can influence the nutritional situation (Hestevik et al., 2020). According to Supariasa (2011) that the family provides positive support for the elderly in maintaining their nutritional status, namely by providing warmth to the elderly, helping to prepare food for the elderly, fulfilling financial resources, respecting and appreciating, providing time and attention, encouraging them to keep abreast of them. Activities outside the home and not providing facilities for regular health checks. Family members also have an influence on the eating habits of other family members (Bloom et al., 2017).

The perceptions and expectations of family members, including not only parents and 
siblings, but also spouses and more distant family members, are generally valued and taken into account by other members (Rodgers, 2012). For the elderly, emphasis is placed on the importance of family, friends and community in supporting them through difficult times and ensuring they are not isolated. This indicates an attachment between family members in achieving something. An understanding of the psychosocial and environmental context, which is built on the resilience of the elderly-family unit, is needed to meet the needs of the elderly who live in the community (Kucukerdonmez et al., 2017). Lack of mutual understanding and joint decisionmaking undermines the involvement of elderly people in their nutritional care. According to the best practice guidelines for elderly nutritional care, respecting the wishes and preferences of the elderly should be the highest priority in nutritional care (Volkert et al., 2019). The involvement of the elderly and their families is emphasized as important in the delivery of nutritional care to the elderly (World Health Organization, 2017). Family involvement can contribute to providing social interaction, physiological care and support, and advocate for better care such as in the nutrition of the elderly (Lao et al., 2019). The family is the closest social environment that is owned by the elderly. Family participation in providing support for elderly care is very important. Family support is the support provided by the family in meeting the needs of the elderly while living their lives so that the elderly feel cared for and appreciated. In providing support, families need sufficient knowledge related to health education in regulating nutrition in families for the elderly to help families to be independent in planning and managing appropriate elderly nutrition.

\section{CONCLUSION}

Family is an important aspect of the life of the elderly. Family has a role in maintaining the health of the elderly, one of which is in fulfilling nutrition. Knowledge, attitudes and family support are related to the nutritional status of the elderly. Families who have knowledge related to nutrition can provide complete food intake and according to the needs of the elderly. A good family attitude will increase their support in helping fulfill nutrition. Family support is not only in providing food, but helps motivate the elderly to increase their appetite and implement certain diets according to their health needs.

\section{REFERENCES}

Aguiar, B., \& Macário, R. (2017). ScienceDirect ScienceDirect The need an Elderly mobility policy Research Centre the need for Elderly centred mobility policy. Transportation Research Procedia, 25, 4355-4369.

https://doi.org/10.1016/j.trpro.2017.05. 309

Badriah, S., \& Sahar, J. (2018). Family support in caring for older people with diabetes mellitus: a phenomenology study. Enfermeria Clinica, 28, 245249.https://doi.org/10.1016/S11308621(18)30077-9

Balitbangkes Kemenkes. (2018). Hasil Utama Riskesdas 2018. Jakarta.

Bloom, I., Lawrence, W., Barker, M., Baird, J., Dennison, E., Sayer, A. A., Robinson, S. (2017). What influences diet quality in older people? A qualitative study among community-dwelling older adults from the Hertfordshire Cohort Study, UK. Public Health Nutrition, 20(15), 2685-2693. https://doi.org/10.1017/S13689800170 01203

Boltz, M., Kuzmik, A., Resnick, B., Trotta, R., Mogle, J., Belue, R., Galvin, J. E. (2018). Reducing disability via a family centered intervention for acutely ill persons with Alzheimer's disease and related dementias : protocol of a clusterrandomized controlled trial (Fam-FFC study), 1-15.

Chaves, C. B., Amaral, O. P., Nelas, P. A., Carvalho, E., \& Dionisio, R. M. (2012). Assessment of Family Functionality Among the Elderly With Chronic Illness.https://doi.org/10.5964/ejcop.v2 i2.31

Fadillah, A. D., Suyatno, \& Nugraheni, S. A. (2019). Faktor-faktor yang berhubungan dengan Kesesuaian Praktik Gizi pada Lansia Berdasarkan 10 Pesan Gizi Seimbang (Studi di Kelurahan Sambiroto Kota Semarang). Jurnal Kesehatan Masyarakat (e-Journal), 7(4), 708-718.

Hestevik, C. H., Molin, M., Debesay, J., Bergland, A., \& Bye, A. (2020). Older patients' and their family caregivers' perceptions of food meals and nutritional care in the transition between hospital and home care: a qualitative study, 1-13.

Jeruszka-bielak, M., Kollajtis- dolowy, A., Santoro, A., Ostan, R., Caumon, E., Gillings, R., Morris, B. J. (2018). Are Nutrition-Related Knowledge and 
Attitudes Reflected in Lifestyle and Health Among Elderly People? A Study Across Five European Countries, 9(July), 1-13. https://doi.org/10.3389/fphys.2018.009 94

Kiesswetter, E., Colombo, M. G., Meisinger, C., Peters, A., Thorand, B., Holle, R. Volkert, D. (2020). Malnutrition and related risk factors in older adults from different health-care settings: An enable study. Public Health Nutrition, 23(3), 446-456. https://doi.org/10.1017/S13689800190 02271

Kristianingrum, N. D., Wiarsih, W., \& Nursasi, A. Y. (2018). Perceived family support among older persons in diabetes mellitus self- management, 18 (Suppl 1), 1-5.

Kucukerdonmez, O., Navruz Varli, S., \& Koksal, E. (2017). Comparison of nutritional status in the elderly according to living situations. Journal of Nutrition, Health and Aging, 21(1), 2530. https://doi.org/10.1007/s12603016-0740-z

Kurata, S., \& Ojima, T. (2014). Knowledge, perceptions, and experiences of family caregivers and home care providers of physical restraint use with homedwelling elders: a cross- sectional study in Japan. BMC Geriatrics, 14(1), 39.

https://doi.org/10.1186/1471- 2318-14-39

Lao, S. S. W., Low, L. P. Le, \& Wong, K. K. Y. (2019). Older residents' perceptions of family involvement in residential care. International Journal of Qualitative Studies on Health and Well-Being, 14(1). https://doi.org/10.1080/1748263 1.2019 .1611298

Lin, W., \& Ms, Y. L. (2005). Nutrition knowledge, attitudes, and dietary restriction behavior of the Taiwanese elderly, 14(June), 221-229.

Lozano, M., Manyes, L., Peiró, J., \& Montes, F. (2019). Geographic conditioning in dietary, social, and health patterns in elderly population with disabilities. Nutrition, 57, 17-23. https://doi.org/10.1016/j.nut.2018.05.0 15

Marinho, M., Medeiros, D. De, Maria, O., Figueredo, C. De, Wanderley, Y., Cunha, R., \& Rodrigues, M. (2020). Factors associated with the overlap of frailty and nutrition in institutionalized older adults: A multicenter study. Archives of Gerontology and Geriatrics,
90(901),

104150.

https://doi.org/10.1016/j.archger.2020. 104150.

Young, A., \& Isenring, E. (2016). The nutrition and food- related roles, experiences and support needs of female family carers of malnourished older rehabilitation patients. Journal of Human Nutrition and Dietetics, 30(1), 16-26. https://doi.org/10.1111/jhn.1239 7

Moral-fernández, L., Frías-osuna, A., Morenocámara, S., Palomino- moral, P. A., \& Del-pino- casado, R. (2018). The start of caring for an elderly dependent family member: a qualitative metasynthesis, 1-14.

Nazari, N., Rusli, Y., \& Tahlil, T. (2016). Dukungan Dan Karakteristik Keluarga Dengan Pemenuhan Nutrisi Pada Lansia. Jurnal IImu Keperawatan, 4(2), 75-86.

Notoatmodjo, S. (2012). Promosi Kesehatan dan Prilaku Kesehatan. Jakarta: Rineka Cipta.

Nurhayati, I., Yuniarti, T., \& Putri, A. P. (2019). Tingkat Pengetahuan Keluarga Dalam Pemberian Gizi Pada Lansia Cepogo, Boyolali. Jurnal Riset Gizi 7(2), 125-130. 125 https://doi.org/10.31983/jrg.v7i 24380

Or, Z., \& Penneau, A. (2018). A Multilevel Analysis of the determinants of emergency care visits by the elderly in France. Health Policy, 122(8), 908914. https://doi.org/10.1016/j.healthp ol.2018.05.003

Péter, S., Saris, W. H. M., Mathers, J. C., Feskens, E., Schols, A., Navis, G., Eggersdorfer, M. (2015). Nutrient status assessment in individuals and populations for healthy aging statement from an expert workshop. Nutrients, 7(12), 10491-10500.

Rodgers, R. (2012). Body Image. In Encyclopedia of Body Image and Human Appearance (pp. 219-225). Elsevier. https://doi.org/10.1016/B9780- 12-384925-0.00040-7.

Schulz, R., Beach, S. R., Czaja, S. J., Martire, L. M., \& Monin, J. K. (2020). Family Caregiving for Older Adults. Annual Review of Psychology, 71(1), 635659. https://doi.org/10.1146/annurevpsych-010419-050754.

Segerstrom, S. C., \& Hodgson, D. M. (2019). ScienceDirect Editorial overview: Psychoneuroimmunology. COBEHA, 28, iii-v. https://doi.org/10.1016/j.cobeha.2019. 
07.009.

Taylor, D. H., \& Hoenig, H. (2006). Access to Health Care Services for the Disabled Elderly, 743- 758. https://doi.org/10.1111/j.14756773.2006.00509.x

Van Hooft, S. M., Dwarswaard, J., Jedeloo, S., Bal, R., \& van Staa, A. L. (2015). Four perspectives on self-management support by nurses for people with chronic conditions: A Q-methodological study. International Journal of Nursing Studies, 52(1), 157- 166. https://doi.org/10.1016/j.jjnurstu.2014. 07.004

Volkert, D., Beck, A. M., Cederholm, T., CruzJentoft, A., Goisser, S., Hooper, L., Sieber, C. C. (2019). ESPEN guideline on clinical nutrition and hydration in geriatrics. Clinical Nutrition, 38(1), 1047.

Vriastuti, V., \& Suratini, S. (2014). Hubungan Dukungan Keluarga dalam Pemenuhan Nutrisi dengan Tekanan Darah Lansia di Mancingan XI, Parangtritis, Kretek, Bantul, Yogyakarta Tahun 2014. STIKES' Aisyiyah Yogyakarta.

WHO. (2014). Global status report on noncommunicable diseases 2014. World Health Organization, 176. https://doi.org/ISBN 9789241564854.

World Health Organization. (2017). Integrated care for older people: guidelines on community-level interventions to manage declines in intrinsic capacity.

World Health Organization (WHO). (2017). Developing an Ethical Framework for Healthy Ageing, (March).

Zhao, Y., Hu, X., \& Men, D. (2019). Design and Research of Health Aids Based on App in the Elderly (Vol. 779). Springer International Publishing. https://doi.org/10.1007/978-3- 31994373-2. 